\title{
Comparison of Cathode Utilization \\ between Polymeric Organodisulfide and Titanium Disulfide in Solid Polymer Electrolyte Rechargeable Lithium Cells
}

\author{
Makoto $\mathrm{UE}^{*}$, Steven J. VISCO ${ }^{\dagger}$ and Lutgard C. DE JONGHE ${ }^{\dagger}$
}

Received June 2, 1993 ; Accepted July 20, 1993

\begin{abstract}
Cathode utilization of a polymeric organodisulfide prepared from 2,5-dimercapto-1,3,4-thiadiazole was compared with that of titanium disulfide in an all-solid-state, thin film, rechargeable cell based on a solid polymer electrolyte operated at $95^{\circ} \mathrm{C}$. The cathode utilization of the polymeric organodisulfide was remarkably enhanced by the use of $\mathrm{LiN}\left(\mathrm{CF}_{3} \mathrm{SO}_{2}\right)_{2}$ instead of $\mathrm{LiCF}_{3} \mathrm{SO}_{3}$ in a polyethylene oxide-based electrolyte and achieved up to $80 \%\left(1.3 \mathrm{mAhcm}^{-2}\right)$ at a $0.5 \mathrm{mAcm}^{-2}$ discharge rate, where $30 \mathrm{wt} \%$ of the active material was loaded in the cathode. The cathode utilization of titanium disulfide was almost the same as the polymeric organodisulfide at equivalent loading levels on a volume basis.
\end{abstract}

\section{INTRODUCTION}

All-solid-state rechargeable lithium cells based on solid polymer electrolytes represented by a complex formed between a polyethylene oxide (PEO) and a lithium metal salt have proposed by Armand ${ }^{1-4)}$.

Subsequently, several groups have shown interest in developing the practical batteries for consumer electronics, load-levelling and electric vehicle applications based on this concept ${ }^{5-8}$.

The cathode materials tested in these advanced batteries can be classified into three categories. The first one includes inorganic intercalation compounds such as titanium disufide ${ }^{6,7)}$, molybdenum dioxide ${ }^{6}$, vanadium oxides ${ }^{5,8-12)}$, titanium dioxide ${ }^{12.13)}$ and manganese dioxide ${ }^{14)}$. The second one consists of electronically conducting polymers such as

${ }^{\dagger}$ Materials Sciences Division, Lawrence Berkeley Laboratory (1 Cyclotron Road, Berkeley, California 94720, USA)

*Present address: Tsukuba Research Centre, Mitsubishi Petrochemical Co., Ltd. (8-3-1 Chuo, Ami, Inashiki, Ibaraki 300-03, Japan)

Key words: Rechargeable lithium cell, Organodisulfide, Titanium disulfide, Polymer electrolyte polyacetylene $^{(5,16)}$, polypyrrole ${ }^{17.18)}$ and polyaniline ${ }^{19)}$.

The last one is a group of polymeric organodisulfides, which has been named solid redox polymerization electrodes (SRPE) due to the reversible polymerizationdepolymerization reaction that occurs on chargedischarge process ${ }^{20-25)}$.

Among polymeric organodisulfides, a polymer prepared from 2,5-dimercapto-1,3,4-thiadiazole (noted as X1) is a promising active material from the point of good reversibility, high open circuit voltage and high energy density based on the simple delocalized structure $^{21,22)}$.<smiles>CC(C)(C)Sc1nnc(SC(C)(C)C)s1</smiles>

In this paper, we will report initial results on how the loading level of an active material in a cathode composite influences the available capacity of a PEObased thin film rechargeable lithium cell operated at $95^{\circ} \mathrm{C}$. As an active material, the $\mathrm{X} 1$ polymer was evaluated in comparison with a reliable inorganic sulfide counterpart, $\mathrm{TiS}_{2}$.

Two kinds of supporting electrolyte salts, $\mathrm{LiCF}_{3} \mathrm{SO}_{3}$ and $\mathrm{LiN}\left(\mathrm{CF}_{3} \mathrm{SO}_{2}\right)_{2}{ }^{26)}$, were used in PEO electrolytes and their performance in the cell was also examined. 


\section{EXPERIMENTAL}

\subsection{Preparation of polymer $X 1$}

The general preparative method is illustrated by the following reactions ${ }^{21,22)}$ :

$$
\begin{aligned}
& \mathrm{HS}-\mathrm{R}-\mathrm{SH}+2 \mathrm{LiOH} \longrightarrow \text { LiS-R-SLi }+2 \mathrm{H}_{2} \mathrm{O} \\
& \mathrm{LiS}-\mathrm{R}-\mathrm{SLi}+\mathrm{I}_{2} \longrightarrow(\mathrm{S}-\mathrm{R}-\mathrm{S})_{\mathrm{n}}+2 \mathrm{LiI}
\end{aligned}
$$

2,5-dimercapto-1,3,4-thiadiazole (Aceto Chemical) was recrystallized twice from acetone to give a white powder.

IR; 3400 (broad), $1500,1450 \mathrm{~cm}^{-1}$. Mp; $161^{\circ} \mathrm{C}$.

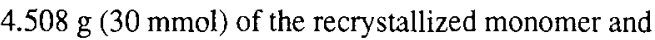
$2.518 \mathrm{~g}(60 \mathrm{mmol})$ of $\mathrm{LiOH} \cdot \mathrm{H}_{2} \mathrm{O}$ (Aldrich) were dissolved in $50 \mathrm{ml}$ of water, respectively. When one equivalent of $\mathrm{LiOH}$ solution was added to the monomer solution, the color of the mixture turned slightly yellow and the addition of another equivalent of $\mathrm{LiOH}$ solution changed it to a colorless solution. The solution was evaporated to dryness and the resultant white powder was washed with hexane and dried in vacuo at $120^{\circ} \mathrm{C}$ for 24 hours. The yield was $6.62 \mathrm{~g}$, which indicated the incorporation of about three water molecules per dithiolate salt.

IR; $3250 \mathrm{~cm}^{-1}$ (broad).

Calcd. for $\mathrm{C}_{2} \mathrm{~N}_{2} \mathrm{~S}_{3} \mathrm{Li}_{2} \cdot 3 \mathrm{H}_{2} \mathrm{O}: \mathrm{C} ; 11.11, \mathrm{H} ; 2.80, \mathrm{~N} ; 12.96$. Found: $\mathrm{C}$; 12.13, H; 2.51, N; 13.53 .

The polymer X1 was prepared without the isolation of the lithium salt. Into the solution of lithium dithiolate (30 mmol), $7.614 \mathrm{~g} \mathrm{(30} \mathrm{mmol)} \mathrm{of} \mathrm{iodine} \mathrm{(J.} \mathrm{T.} \mathrm{Baker)}$ was added and heated at $75^{\circ} \mathrm{C}$ for 2 hours to give a slightly yellow precipitate. The precipitate was washed with boiling water, hot acetone, methanol, hexane and ether successively and dried in vacuo at $120^{\circ} \mathrm{C}$ for 24 hours to give $3.74 \mathrm{~g}$ ( $84 \%$ in yield) of the polymer, which was ground into a fine powder.

IR; $1500,1475,1450 \mathrm{~cm}^{-1}$. Decomp. temp.; $188^{\circ} \mathrm{C}$.

Calcd. for $\left(\mathrm{C}_{2} \mathrm{~N}_{2} \mathrm{~S}_{3}\right)_{\mathrm{n}}: \mathrm{C} ; 16.21, \mathrm{~N} ; 18.90, \mathrm{~S} ; 64.90$.

Found: $\mathrm{C} ; 16.13, \mathrm{~N} ; 18.60, \mathrm{~S} ; 65.00$.

Impurities: Li; 57 ppm, Na; 27 ppm.

\subsection{Preparation of cathode and electrolyte films}

Cathode films were prepared from polymer X1 powder or $\mathrm{TiS}_{2}$ powder (Cerac), Shawinigan acetylene black powder (Chevron Chemical), Brij 35 (Aldrich) as a dispersant and PEO $\left(5 \times 10^{6}\right.$ in average molecular weight, Aldrich). Electrolyte films were prepared from
$\mathrm{LiCF}_{3} \mathrm{SO}_{3}(3 \mathrm{M})$ or $\mathrm{LiN}\left(\mathrm{CF}_{3} \mathrm{SO}_{2}\right)_{2}(3 \mathrm{M})$ and the same PEO. All materials were dried under vacuum at $50^{\circ} \mathrm{C}$ for several days and stored under helium atmosphere.

When the loading level of active materials was changed, the amount ratios of acetylene black and Brij 35 to the active material were kept constant as shown in Table 1. The ratio of $\mathrm{Li}^{+}$ion to an ethylene oxide monomer unit in the polymer electrolytes was adjusted to $1: 8$ as shown in Table 2 .

A viscous slurry mixture was obtained in acetonitrile (HPLC grade, Aldrich) by vigorous stirring with a highspeed homogenizer. Appropriate amounts of the homogenized mixtures depending on the desired film thickness were cast into glass rings $(41.8 \mathrm{~mm}$ in diameter) placed on a clean Teflon surface and the solvent was allowed to evaporate in air overnight.

The thin cathode film ( $30-120 \mu \mathrm{m}$ in thickness) and the thin electrolyte film ( $35-45 \mu \mathrm{m}$ in thickness) were peeled off and were cut into disks (16.0 and $25.0 \mathrm{~mm}$ in diameter, respectively) and dried under vaccum at $50^{\circ} \mathrm{C}$ for several days and stored under helium atomosphere. These films were subjected to vacuum drying prior to use.

Table 1. Formulation of cathode mixtures.

\begin{tabular}{lcc}
\hline \multirow{2}{*}{ material } & \multicolumn{2}{c}{ loading level } \\
\cline { 2 - 3 } & $30 \mathrm{wt} \%$ & $45 \mathrm{wt} \%$ \\
\hline PEO (MW = $\left.5 \times 10^{6}\right)$ & $600 \mathrm{mg}$ & $400 \mathrm{mg}$ \\
Polymer X1 or TiS 2 & $300 \mathrm{mg}$ & $450 \mathrm{mg}$ \\
Acetylene black & $70 \mathrm{mg}$ & $105 \mathrm{mg}$ \\
Brij 35 & $30 \mathrm{mg}$ & $45 \mathrm{mg}$ \\
$\mathrm{CH}_{3} \mathrm{CN}$ & $22 \mathrm{ml}$ & $15 \mathrm{ml}$ \\
\hline
\end{tabular}

Table 2. Formulation of electrolyte mixtures.

\begin{tabular}{lcc}
\hline material & A & B \\
\hline $\mathrm{PEO}\left(\mathrm{MW}=5 \times 10^{6}\right)$ & $693 \mathrm{mg}$ & $551 \mathrm{mg}$ \\
$\mathrm{LiCF}_{3} \mathrm{SO}_{3}$ & $307 \mathrm{mg}$ & - \\
$\mathrm{LiN}\left(\mathrm{CF}_{3} \mathrm{SO}_{2}\right)_{2}$ & - & $449 \mathrm{mg}$ \\
$\mathrm{CH}_{3} \mathrm{CN}$ & $40 \mathrm{ml}$ & $30 \mathrm{ml}$ \\
\hline
\end{tabular}




\subsection{Estimation of film thickness}

Thickness ( $t$ ) of the films was estimated using apparent densities (d) of the films, which were calculated based on physical mixing of each component. Densities of $\mathrm{Li}, \mathrm{PEO}$, polymer $\mathrm{X} 1, \mathrm{TiS}_{2}$, acètylene black, Brij 35, $\mathrm{LiCF}_{3} \mathrm{SO}_{3}$ and $\mathrm{LiN}\left(\mathrm{CF}_{3} \mathrm{SO}_{2}\right)_{2}$ were $0.53,1.21,1.60,3.22,2.26,0.95,1.90$ and 1.91 , respectively. Estimated thickness of the films agreeded with the measured values within $10 \%$ in error.

\subsection{Assembly and evaluation of test cells}

Battery-grade lithium foil $(25 \mu \mathrm{m}$ in thickness, Lithco) was cut into disks (18.4 $\mathrm{mm}$ in diameter) and test cells were assembled using exterior cases of 2016 coin cells as shown in Fig. 1. A screw clamp was used to apply slight pressure on the assembled cell. The cell was maintained in a furnace thermostatted at $95 \pm 2^{\circ} \mathrm{C}$.

All the above procedures were carried out inside a helium glove box equipped with a moisture removing apparatus (Vacuum Atmospheres).

Discharge-charge characteristics were examined with a galvanostat (Princeton Applied Research, model 371) controlled by a personal computer (IBM, PC/AT) equipped with a D/A board and developed software ${ }^{27}$.

Test cells were discharged/charged at $0.5 / 0.1 \mathrm{mAcm}^{-2}$ between 3.1 and $2.0 \mathrm{~V}\left(1.5 \mathrm{~V}\right.$ for $\left.\mathrm{TiS}_{2}\right)$. Open circuit voltages of the cell were monitored periodically in order to know the polarization. Cell impedances were also measured before and after discharge by a pulse technique. Because large cell impedance $\left(>70 \Omega \mathrm{cm}^{-2}\right.$ ) occasionally resulted from poor contact between cell components and these cells generally showed poor discharge behavior.

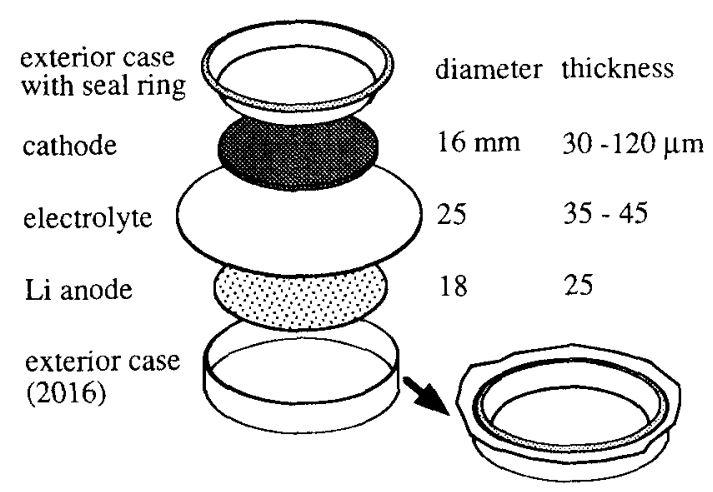

Fig. 1. A schematic view of a test cell.

\section{RESULTS AND DISCUSSION}

\subsection{Discharge-charge profile}

Representative discharge-charge curves both for $\mathrm{Li} /$ $\mathrm{X} 1$ and $\mathrm{Li} / \mathrm{TiS}_{2}$ cells using a PEO-LiCF $\mathrm{SO}_{3}$ electrolyte are shown in Fig. 2, where cell voltage (E) was plotted against capacity $(Q)$. Since all cells were constructed cathode-limited, theoretical capacities were derived by weighing the cathode films.

The polymer X1 cathode always shows two plateaus, which come from the different electrode potentials of the reactions, polymer to dimer and dimer to monomer:

$$
\begin{aligned}
& (\mathrm{S}-\mathrm{R}-\mathrm{S})_{\mathrm{n}}+\mathrm{nLi}^{+}+\mathrm{ne} \longrightarrow \mathrm{n} / 2(\mathrm{LiS}-\mathrm{R}-\mathrm{S})_{2} \\
& \mathrm{n} / 2(\mathrm{LiS}-\mathrm{R}-\mathrm{S})_{2}+\mathrm{nLi}^{+}+\mathrm{ne} \rightarrow \mathrm{nLiS}-\mathrm{R}-\mathrm{SLi}(3)
\end{aligned}
$$

This observation was also confirmed in the solution containing the monomer by cyclic voltammetry ${ }^{28,29)}$

Although the $\mathrm{TiS}_{2}$ cathode initially shows a high open circuit voltage around $3.0 \mathrm{~V}$, the potential falls rapidly upon discharge. Iit decreases constantly with time, because the electrode potential of the cathode decreases as the following reaction proceeds:

$$
\mathrm{Li}^{+}+\mathrm{TiS}_{2}+\mathrm{e}^{-} \longrightarrow \mathrm{LiTiS}_{2}
$$

The dischrge-charge curve fairly agrees with the curves reported for $\mathrm{Li} / \mathrm{p}(\mathrm{EO})_{8} \mathrm{LiClO}_{4} / \mathrm{TiS}_{2}{ }^{6}$, although it was reported that $\mathrm{LiCF}_{3} \mathrm{SO}_{3}$ was inferior to $\mathrm{LiClO}_{4}$ in $\mathrm{Li} / \mathrm{PEO}-\mathrm{LiX} / \mathrm{TiS}_{2}$ cells $^{6.21)}$.

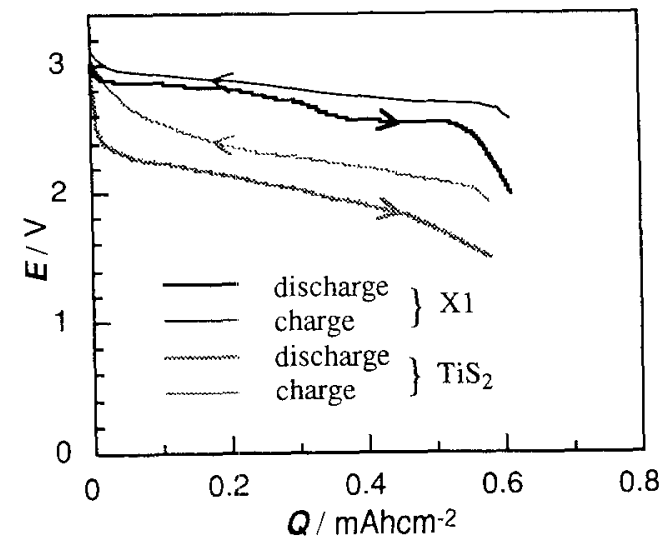

Fig. 2. Typical discharge-charge curves for $\mathrm{Li} /$ $\mathrm{p}(\mathrm{EO})_{8} \mathrm{LiCF}_{3} \mathrm{SO}_{3} / \mathrm{X} 1$ and $\mathrm{Li} / \mathrm{p}(\mathrm{EO})_{8} \mathrm{LiCF}_{3} \mathrm{SO}_{3} / \mathrm{TiS}_{2}$ cells at $95^{\circ} \mathrm{C}$.

theoretical capacity: $0.75 \mathrm{mAhcm}^{-2}$ ( $30 \mathrm{wt} \%$ loading), discharge rate: $0.5 \mathrm{mAcm}^{-2}$, charge rate: $0.1 \mathrm{mAcm}^{-2}$. 


\subsection{Cathode utilization}

The capacity of the test cell was varied from 0.6 to 2.3 mAhcm ${ }^{-2}$ by changing the amount of an active material in the cathode in two ways, by changing thickness of the cathode film and changing a mixing ratio of an active material in the cathode composites (loading level).

The first discharge curves of the test cells using a $\mathrm{p}(\mathrm{EO})_{8} \mathrm{LiCF}_{3} \mathrm{SO}_{3}$ or a $\mathrm{p}(\mathrm{EO})_{8} \mathrm{LiN}\left(\mathrm{CF}_{3} \mathrm{SO}_{2}\right)_{2}$ electrolyte were shown in Fig. 3, 4, 5 and 6 for $\mathrm{Li} / \mathrm{X} 1$ and Fig. 7, 8, 9 and 10 for $\mathrm{Li} / \mathrm{TiS}_{2}$ cells, respectively.

Horizontal axes of all figures are represented by the cathode utilization (U), which indicates the ratio of available capacity $(Q)$ to theoretical capacity $\left(Q_{\mathrm{r}}\right)$.

Theoretical capacity of each cell is given in the figures

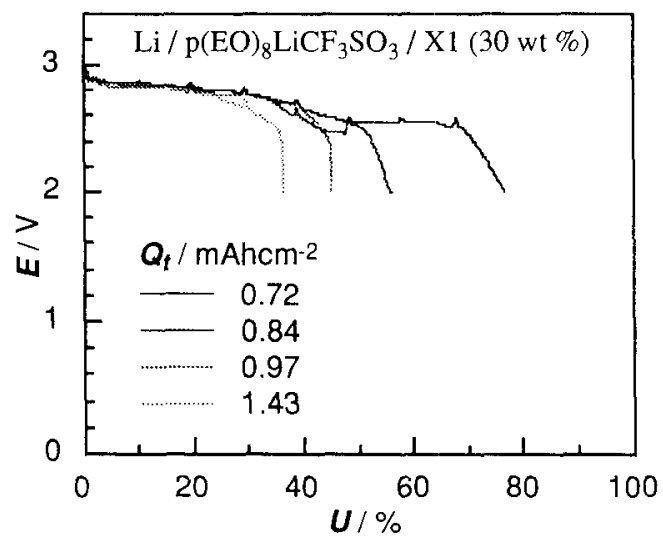

Fig. 3. Discharge curves at $0.5 \mathrm{mAcm}^{-2}$ for Li / $\mathrm{p}(\mathrm{EO})_{8} \mathrm{LiCF}_{3} \mathrm{SO}_{3} / \mathrm{X} 1(30 \mathrm{wt} \%)$ at $95^{\circ} \mathrm{C}$.

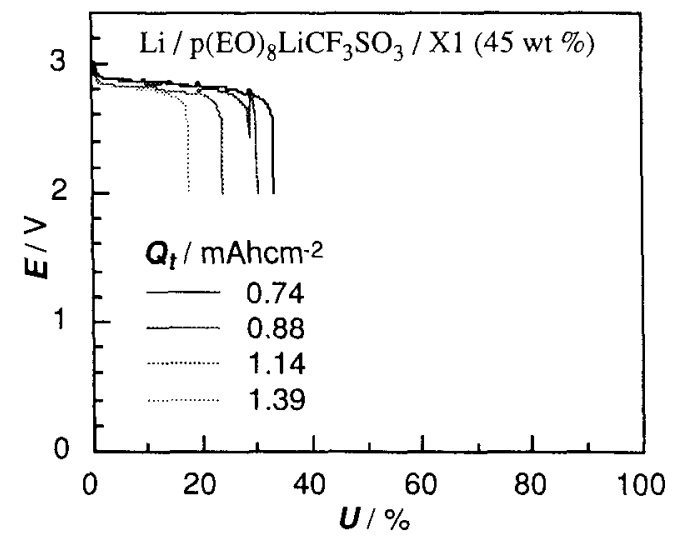

Fig. 4. Discharge curves at $0.5 \mathrm{mAcm}^{-2}$ for $\mathrm{Li} /$ $\mathrm{p}(\mathrm{EO})_{8} \mathrm{LiCF}_{3} \mathrm{SO}_{3} / \mathrm{X} 1(45 \mathrm{wt} \%)$ at $95^{\circ} \mathrm{C}$. and the corresponding film thickness to the theoretical capacity can be estimated from the conversion coefficients $\left(t / Q_{L}\right)$ given in Table 3.

Table 3. Estimated density and thickness of the cathode composites.

\begin{tabular}{lcc}
\hline cathode composite & $\begin{array}{c}d \\
/ \mathrm{gcm}^{-3}\end{array}$ & $\begin{array}{c}t / Q_{t} \\
/ \mu \mathrm{m} / \mathrm{mAhcm}-2\end{array}$ \\
\hline 30 wt \% polymer X1 & 1.34 & 68.8 \\
45 wt \% polymer X1 & 1.42 & 43.3 \\
30 wt \% TiS 2 & 1.53 & 91.1 \\
45 wt \% TiS & 1.77 & 52.4 \\
\hline
\end{tabular}

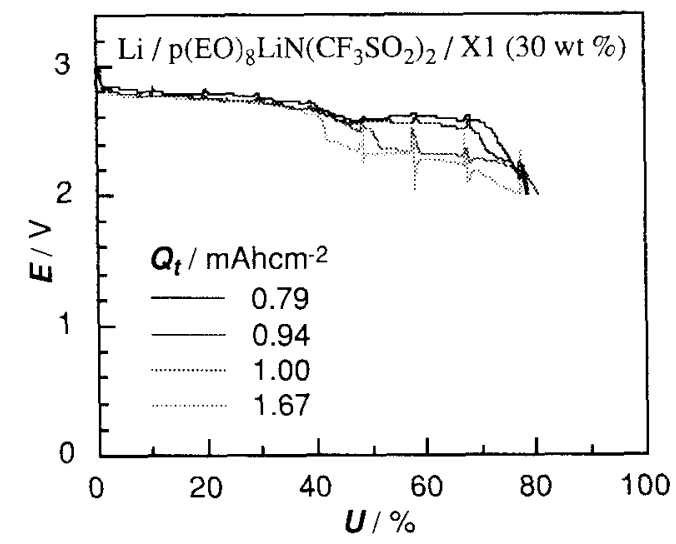

Fig. 5. Discharge curves at $0.5 \mathrm{mAcm}^{-2}$ for $\mathrm{Li} /$ $\mathrm{p}(\mathrm{EO})_{8} \mathrm{LiN}\left(\mathrm{CF}_{3} \mathrm{SO}_{2}\right)_{2} / \mathrm{X} 1(30 \mathrm{wt} \%)$ at $95^{\circ} \mathrm{C}$.

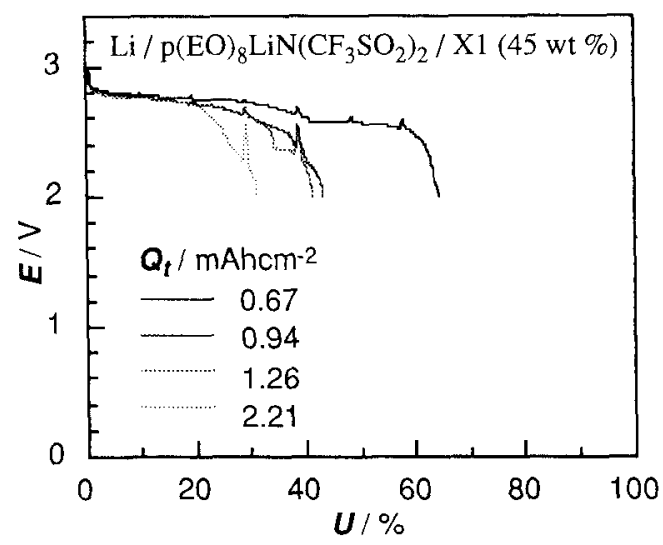

Fig. 6. Discharge curves at $0.5 \mathrm{mAcm}^{-2}$ for $\mathrm{Li} /$ $\mathrm{p}(\mathrm{EO})_{8} \mathrm{LiN}\left(\mathrm{CF}_{3} \mathrm{SO}_{2}\right)_{2} / \mathrm{X} 1(45 \mathrm{wt} \%)$ at $95^{\circ} \mathrm{C}$. 
The following three factors on the cathode utilization can be discussed from these results both for $\mathrm{Li} / \mathrm{X} 1$ and $\mathrm{Li} / \mathrm{TiS}_{i}$ cells.

i. Thickness of a cathode film

ii. Loading level of an active material in a cathode film

iii. Kind of a supporting salt ( $\mathrm{LiX}$ ) in a PEO-based electrolyte

The values of cathode utilization obtained in each cell were plotted against the thickness of the cathode films in Fig. 12 for $\mathrm{Li} / \mathrm{X} 1$ and Fig. 13 for Li/TiS.

\section{(a) $\mathrm{Li} / \mathrm{XI}$ cell}

The cathode utilization generally became lower as the thickness of the cathode film and the loading level of

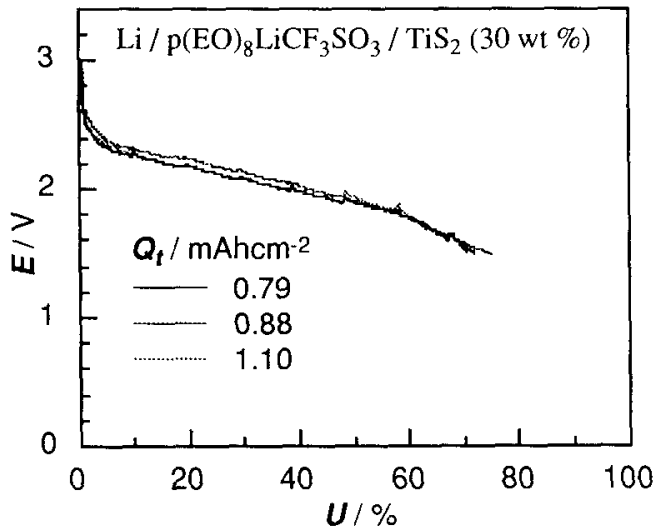

Fig. 7. Discharge curves at $0.5 \mathrm{mAcm}^{-2}$ for Li / $\mathrm{p}(\mathrm{EO})_{8} \mathrm{LiCF}_{3} \mathrm{SO}_{3} / \mathrm{TiS}_{2}(30 \mathrm{wt} \%)$ at $95^{\circ} \mathrm{C}$.

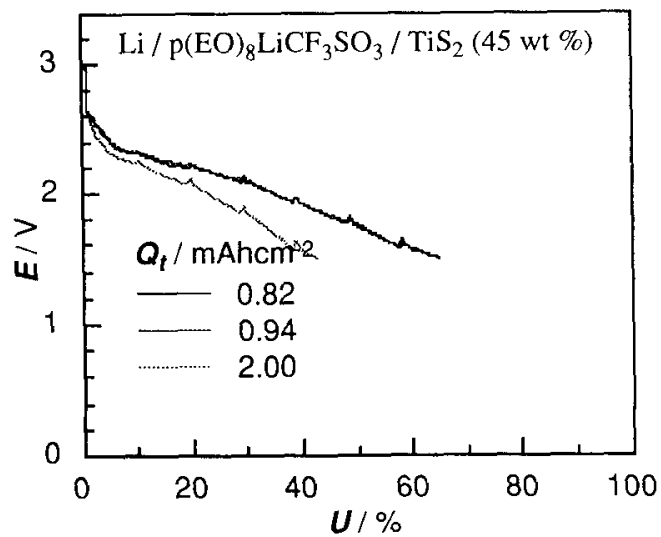

Fig. 8. Discharge curves at $0.5 \mathrm{mAcm}^{-2}$ for Li / $\mathrm{p}(\mathrm{EO})_{8} \mathrm{LiCF}_{3} \mathrm{SO}_{3} / \mathrm{TiS}_{2}(45 \mathrm{wt} \%)$ at $95^{\circ} \mathrm{C}$.
$\mathrm{X} 1$ in the cathode increased as shown in Fig. 3 vs. 4 and Fig. 5 vs. 6. It is believed that this is because of the inadequate transport of $\mathrm{Li}^{+}$in the cathode composite.

However, the utilization of $\mathrm{LiN}\left(\mathrm{CF}_{3} \mathrm{SO}_{2}\right)_{2}$ as a supporting salt in the polymer electrolyte markedly enhanced the cathode utilization as shown in Fig. 3 vs. 5 and Fig. 4 vs. 6. Particularly, $\mathrm{Li} / \mathrm{p}(\mathrm{EO})_{8} \mathrm{LiN}\left(\mathrm{CF}_{3} \mathrm{SO}_{2}\right)_{2}$ / X1 (30 wt \%) cell showed no decline of the cathode utilization as shown in Fig. 12.

It is known that the conductivity of $\mathrm{p}(\mathrm{EO})_{8} \mathrm{LiClO}_{4}$ at $95^{\circ} \mathrm{C}\left(10^{-3} \mathrm{~S} \mathrm{~cm}^{-1}\right)$ is about ten times higher than that of $\mathrm{p}(\mathrm{EO})_{8} \mathrm{LiCF}_{3} \mathrm{SO}_{3}$, because $\mathrm{p}(\mathrm{EO})_{8} \mathrm{LiClO}_{4}$ has a lower glass temperature than $\mathrm{p}(\mathrm{EO})_{8} \mathrm{LiCF}_{3} \mathrm{SO}_{3}{ }^{3)}$. The conductivity of $\mathrm{p}(\mathrm{EO})_{8} \mathrm{LiN}\left(\mathrm{CF}_{3} \mathrm{SO}_{2}\right)_{2}$ at $95^{\circ} \mathrm{C}$ is almost

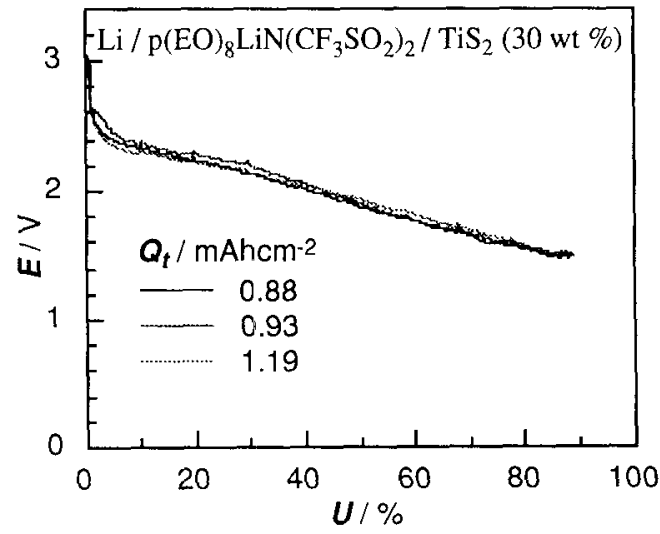

Fig. 9. Discharge curves at $0.5 \mathrm{mAcm}^{-2}$ for $\mathrm{Li} /$ $\mathrm{p}(\mathrm{EO})_{8} \mathrm{LiN}\left(\mathrm{CF}_{3} \mathrm{SO}_{2}\right)_{2} / \mathrm{TiS}_{2}(30 \mathrm{wt} \%)$ at $95^{\circ} \mathrm{C}$.

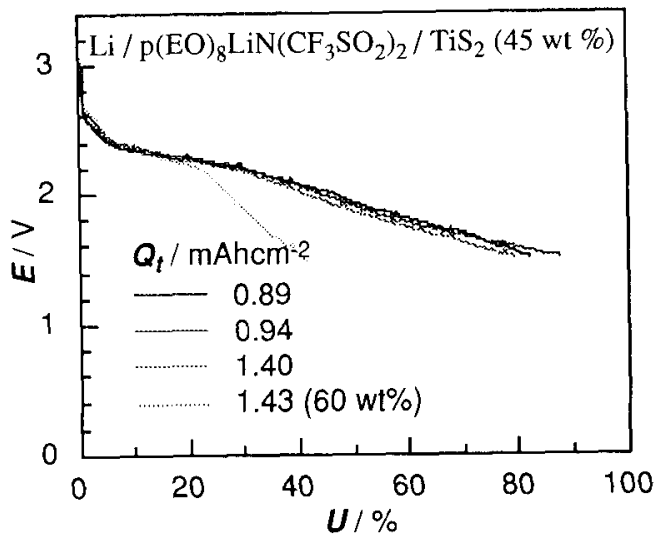

Fig. 10. Discharge curves at $0.5 \mathrm{mAcm}^{-2}$ for $\mathrm{Li} /$ $\mathrm{p}(\mathrm{EO})_{8} \mathrm{LiN}\left(\mathrm{CF}_{3} \mathrm{SO}_{2}\right)_{2} / \mathrm{TiS}_{2}(45 \mathrm{wt} \%)$ at $95^{\circ} \mathrm{C}$. 
the same as that of $\mathrm{p}(\mathrm{EO})_{8} \mathrm{LiClO}_{4}{ }^{30}$ and the $\mathrm{p}(\mathrm{EO})_{8} \mathrm{LiN}\left(\mathrm{CF}_{3} \mathrm{SO}_{2}\right)_{2}$ film has a similar elastic character (softness and stickiness) with the $\mathrm{p}(\mathrm{EO})_{8} \mathrm{LiClO}_{4}$ film.

The enhancement in the cathode utilization caused by $\mathrm{LiN}\left(\mathrm{CF}_{3} \mathrm{SO}_{2}\right)_{2}$ is explained by this conductivity enhancement of the polymer electrolyte, itself.

However, the improvement of the contact between the electrolyte and the cathode by the elastic character of the $\mathrm{p}(\mathrm{EO})_{8} \mathrm{LiN}\left(\mathrm{CF}_{3} \mathrm{SO}_{2}\right)_{2}$ film should be considered, because the addition of a small amount of $\mathrm{LiN}\left(\mathrm{CF}_{3} \mathrm{SO}_{2}\right)_{2}$ in the cathode increased the cathode utilization of a $\mathrm{Li} / \mathrm{p}(\mathrm{EO})_{8} \mathrm{LiCF}_{3} \mathrm{SO}_{3} / \mathrm{X} 1$ cell as shown in Fig. 11.

\section{(b) $\mathrm{Li} / \mathrm{TiS}$, cell}

Similar tendencies have observed for $\mathrm{Li} / \mathrm{TiS}$, cell as far as the cathode utilization is concerned. However, only $\mathrm{Li} / \mathrm{p}(\mathrm{EO})_{8} \mathrm{LiCF}_{3} \mathrm{SO}_{3} / \mathrm{TiS}_{2}(45 \mathrm{wt} \%$ ) cell showed a decline of the cathode utilization as shown in Fig. 13.

Since the density of $\mathrm{TiS}_{2}$ is twice that of $\mathrm{X} 1$, smaller volume occupied by $\mathrm{TiS}_{2}$ in the cathode film resulted in the better cathode utilization than $\mathrm{X} 1$ at the same loading levels based on weight. However, the cathode utilization of $\mathrm{Li} / \mathrm{TiS} \mathrm{S}_{2}$ cells became almost the same as $\mathrm{Li} / \mathrm{X} 1$ cell, if loading level on a volume basis was taken into account.

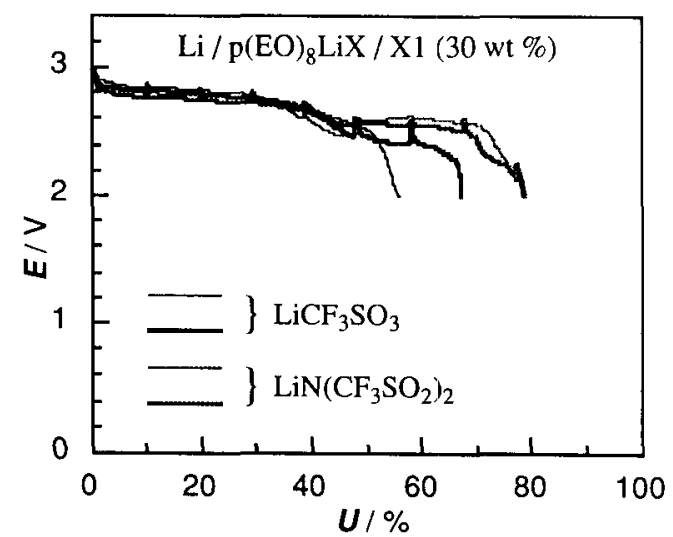

Fig. 11. Addition effect of $\mathrm{LiN}\left(\mathrm{CF}_{3} \mathrm{SO}_{2}\right)_{2}(\mathrm{Li} / \mathrm{EO}=1 / 16)$ in the cathode of $\mathrm{Li} / \mathrm{p}(\mathrm{EO})_{8} \mathrm{LiX} / \mathrm{X} 1(30 \mathrm{wt} \%)$ cells. theoretical capacity: $0.85 \mathrm{mAhcm}^{-2}$, discharge rate: $0.5 \mathrm{mAcm}^{-2}$ at $95^{\circ} \mathrm{C}$, bold lines: $\mathrm{LiN}\left(\mathrm{CF}_{3} \mathrm{SO}_{2}\right)_{2}$ added.
Loading levels of $30 \mathrm{wt} \% \mathrm{X} 1$ and $45 \mathrm{wt} \% \mathrm{TiS}_{2}$ are equivalent to $25 \mathrm{vol} \%$ for both $\mathrm{X} 1$ and $\mathrm{TiS}_{2}$.

Furthermore, the cathode utilization of $60 \mathrm{wt} \%$ (35 vol \%) loading of $\mathrm{TiS}_{2}$ declined as shown in Fig. 10 and it coincided with that of $45 \mathrm{wt} \%$ ( $40 \mathrm{vol} \%$ ) loading of $\mathrm{X} 1$. This observation indicates $\mathrm{Li}^{+}$transport in the cathode composite may be impeded by the existing volume of active materials.

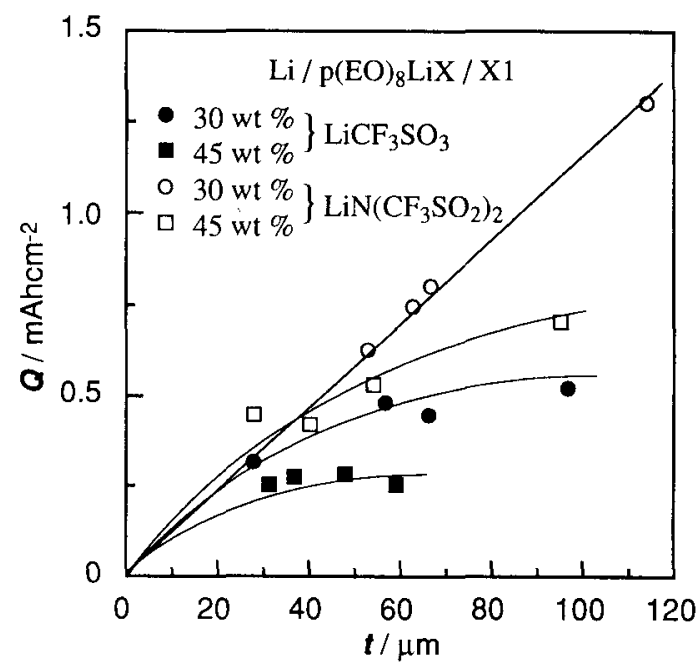

Fig. 12. Available capacity of $\mathrm{Li} / \mathrm{p}(\mathrm{EO})_{8} \mathrm{LiX} / \mathrm{X} 1$ cells as a function of cathode film thickness.

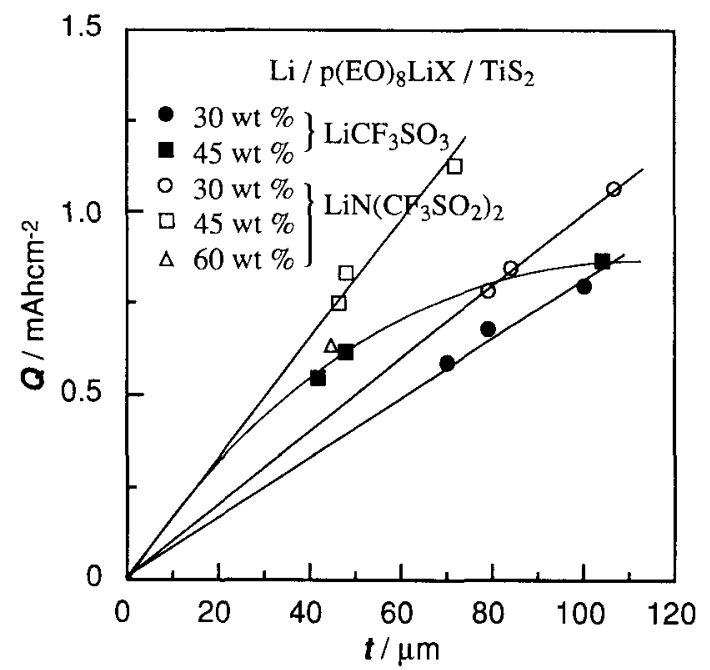

Fig. 13. Available capacity of $\mathrm{Li} / \mathrm{p}(\mathrm{EO})_{8} \mathrm{LiX} / \mathrm{TiS}_{2}$ cells as a function of cathode film thickness. 


\subsection{Calculation of energy density and power density}

On the basis of the experimental results, energy densities (W) and sustained power densities (P) of Li/ $\mathrm{X} 1$ and $\mathrm{Li} / \mathrm{TiS}_{2}$ cells were calculated volumetrically $\left(_{\mathrm{v}}\right.$ ) and gravimetrically $\left(_{g}\right)$ as shown in Fig. 14. The cell capacity was fixed to $1 \mathrm{mAhcm}^{-2}$ at $0.5 \mathrm{mAcm}^{-2}$ discharge rate, which is comparable with reported values $\left(0.4^{5)}, 0.97^{6)}, 1.45^{7)}, 1.5^{8)} \mathrm{mAhcm}^{-2}\right)$.

\section{$\mathrm{Li} / \mathrm{p}(\mathrm{EO})_{8} \mathrm{LiN}\left(\mathrm{CF}_{3} \mathrm{SO}_{2}\right)_{2} / \mathrm{Xl}(30 \mathrm{wt} \%)$}

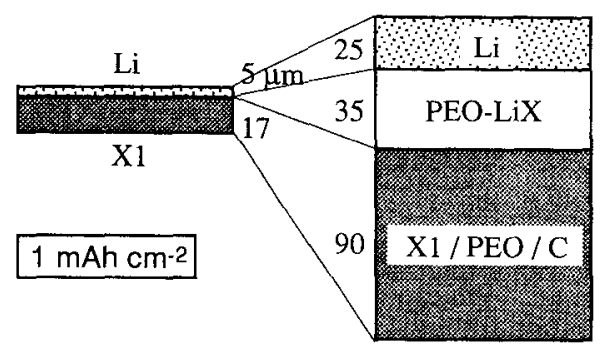

$$
\begin{array}{ll}
\mathrm{E}_{\mathrm{O}}=3.0 \mathrm{~V} & \mathrm{E}_{\mathrm{m}}=2.5 \mathrm{~V} \\
\mathrm{~W}_{\mathrm{v}}=1350 \mathrm{Wh} \mathrm{l}^{-1} & \mathrm{~W}_{\mathrm{v}}=166 \mathrm{Wh} \mathrm{l}^{-1} \\
\mathrm{~W}_{\mathrm{g}}=990 \mathrm{Wh} \mathrm{kg}^{-1} & \mathrm{~W}_{\mathrm{g}}=136 \mathrm{Wh} \mathrm{kg}^{-1} \\
\text { (Theoretical) } & \mathrm{P}_{\mathrm{v}}=83 \mathrm{Wl}^{-1}(\mathrm{C} / 2) \\
& \mathrm{P}_{\mathrm{g}}=67 \mathrm{~W} \mathrm{~kg}^{-1}
\end{array}
$$$$
\text { (Practical) }
$$

Current collectors were neglected and cathode utilization was assumed to be $75 \%$. An average cell voltage $\left(E_{m}\right)$ was used instead of an initial value $\left(E_{0}\right)$.

In spite of a lower loading level on a weight basis, the $\mathrm{Li} / \mathrm{X} 1$ cell affords higher enegy and power density than the $\mathrm{Li} / \mathrm{TiS}_{2}$ cell, because of a higher cell voltage and a lower equivalent weight ( 74 for $\mathrm{X} 1$ and 112 for $\mathrm{TiS}_{2}$ ).

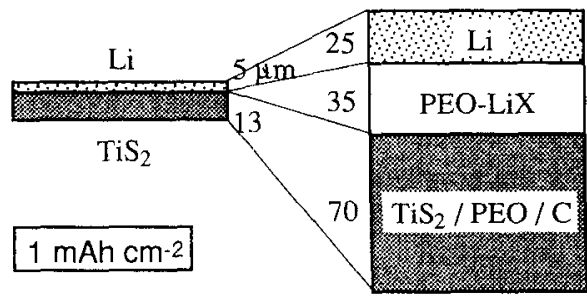

$$
\begin{array}{ll}
\mathrm{E}_{0}=2.5 \mathrm{~V} & \mathrm{E}_{\mathrm{In}}=2.0 \mathrm{~V} \\
\mathrm{~W}_{\mathrm{v}}=1400 \mathrm{Wh} \mathrm{l}^{-1} & \mathrm{~W}_{\mathrm{v}}=154 \mathrm{Wh} \mathrm{l}^{-1} \\
\mathrm{~W}_{\mathrm{g}}=500 \mathrm{Wh} \mathrm{kg-1}^{-1} & \mathrm{~W}_{\mathrm{g}}=106 \mathrm{Wh} \mathrm{kg-1}^{-1} \\
\text { (Theoretical) } & \mathrm{P}_{\mathrm{v}}=77 \mathrm{~W} \mathrm{I}^{-1}(\mathrm{C} / 2) \\
& \mathrm{P}_{\mathrm{g}}=53 \mathrm{~W} \mathrm{~kg}^{-1} \\
& \text { (Practical) }
\end{array}
$$

Fig. 14. Estimation of energy density and sustained power density for thin film rechargeble lithium cells.

\section{RFFERENCES}

1) M. B. Armand, J. M. Chabagno and M. J. Duclot, Fast Ion Transport in Solids, P. Vashitsta, J. N. Mundy and G. K. Shenoy, ed., p.131, Elsevier Publishing Co., New York (1979).

2) Solid state batteries NATO ASI series, C. A. C. Sequeira and A. Hooper ed., Martinus Nijhoff Publishers, Dordrecht (1985).

3) Polymer Electrolyte Reviews-1, J. R. MacCallum and C. A. Vincent, ed., Elsevier Applied Science Publishers, London (1987).

4) M. Gauthier, M. Armand and D. Muller, Electroresponsive Molecular and Polymeric Systems Vol. 1., T. A. Skotheim ed. p. 41, Marcel Dekker, New York (1988).

5) A. Hooper and J. M. North, Solid State lonics, 9-10, 1161 (1983).
6) M. Gauthier, D. Fauteux, G. Vassort, A. Bélanger, M. Duval, P. Ricoux, J. M. Chabagno, D. Muller, P. Rigaud, M. B. Armand and D. Deroo, J. Electrochem. Soc., 132, 1333 (1985).

7) K. M. Abraham, M. Alamgir and S. J. Perrotti, J. Electrochem. Soc., 135, 535 (1988).

8) Y. Nakacho, Y. Tada, A. Inubushi, S. Masuda and M. Taniguchi, Proc. 29th Bat. Symp. Jpn., p 205 (1988).

9) K. West, B. Zachau-Christiansen, M. J. L. Østergård and T. Jacobsen, J. Power Sources, 20, 165 (1987).

10) F. Bonino, M. Ottaviani, B. Scrosati and G. Pistoia, J. Electrochem. Soc., 135, 12 (1988).

11) M. Z. A. Munshi and B. B. Owens, Solid State Ionics, 26, 41 (1988).

12) M. G. Minett and J. R. Owen, J. Power Sources, 32, 81 (1990). 
13) W. J. Macklin and R. J. Neat, Solid State Ionics, 53-56, 694 (1992).

14) W. J. Macklin, R. J. Neat and R. J. Powell, J. Power Sources, 34, 39 (1991).

15) T. Nagatomo, C. Ichikawa and Q. Omoto, J. Electrochem. Soc., 134, 305 (1987).

16) D. Billaud, S. Lemont and R. Yazami, Electrohimica Acta, 37, 1675 (1992).

17) P. Novák, O. Inganäs and R. Bjorklund, J. Electrochem. Soc., 134, 1341 (1987).

18) F. Croce, S. Panero, P. Prosperi and B. Scrosati, Solid State Ionics, 28-30, 895 (1988).

19) L. S. Yang, Z. Q. Shan and Y. D. Liu, Solid State Ionics, 40-41, 967 (1990).

20) S. J. Visco, M. Liu, M. B. Armand and L. C. De Jonghe, Mol. Cryst. Liq. Cryst.,190,185 (1990).

21) M. Liu, S. J. Visco and L. C. De Jonghe, J. Electrochem. Soc., 138, 1891 (1991).

22) M. M. Doeff, S. J. Visco and L. C. De Jonghe, J. Electrochem. Soc., 139, 1808 (1992).
23) M. M. Lemer, S. J. Visco, M. Ue, M. M. Doeff and L. C. De Jonghe, Mat. Res. Soc. Symp. Proc., 210, 81 (1991).

24) M. M. Doeff, M. M. Lemer, S. J. Visco and L. C. De Jonghe, J. Electrochem. Soc., 139, 2077 (1992).

25) The organosulfur battery technology is proprietary to Poly Plus, Inc., 809 Bancroft Way, Berkeley, California 94710 , USA.

26) M. Armand and F. Moursli, U .S. Pat., 4505997 (1985).

27) S. J. Visco and M. Liu, J. Appl. Electrochem., 22, 307 (1992).

28) K. Naoi, M. Menda, H. Ooike and N. Oyama, J. Electroanalytical Chem., 318, 395 (1991).

29) T. Sotomura, H. Uemachi, K. Naoi and N. Oyama, Electrochimica Acta, 37, 1851 (1992).

30) M. Armand, unpublished data. 